\title{
Adverse Drug Reactions Study of Antihypertensive Drugs in Primary Care Settings
}

\author{
Yeni Farida*, Kharimah Faizathus Tsalatsatun \\ Universitas Sebelas Maret, Surakarta, Jawa Tengah \\ Submitted: 17-06-2020 Revised: 24-09-2020 \\ Korespondensi : Yeni Farida : Email : yenifarida@staff.uns.ac.id
}

Accepted: $18-12-2020$

\begin{abstract}
Hypertension is one of the high-prevalence diseases in primary care. Failure to achieve the target of blood pressure is affected by non-compliance due to the antihypertensive adverse reactions. This study aims to determine adverse drug reaction (ADR) of antihypertensive drugs in primary care settings. A cross sectional study was conducted in "Sibela" Primary Care in Surakarta on March 2019. Investigators interviewed patients directly and observed supporting data from medical records. Hypertension patients with antihypertensive drugs at least for a month were eligible in this study. Then, the data were analyzed by the Liverpool algorithm that interpreted in 4 scales: unlikely, possible, probable, and definite. A total 70 subject were dominated by female (80\%). Monotherapy of antihypertensive drugs prescribed to patient in primary care were amlodipine $(80 \%)$ and captopril (10\%). Nine events of ADR were found in hypertension patient. None ADR were doubtful. Possible ADR of amlodipine was drowsiness (5.4\%), whereas probable ADR were nausea (3.4\%), diuresis (1.8\%), and abdominal pain (1.8\%). Definite ADR of captopril was dry mouth (14.3\%) and probable ADR was abdominal pain (14.3\%). Further investigation regarding the drowsiness, ADR of amlodipine, was needed.
\end{abstract}

Keywords: antihypertensive drugs; Liverpool Algorithm; primary care; ADR

\section{INTRODUCTION}

Based on the health profile of Central Java province, and especially Surakarta city in 2017, hypertension was ranked the first for non-communicable disease with a total of 25,855 cases $^{1}$. Hypertension is one of the mostcommonly found diseases at primary health facilities. The prevalence of hypertension among adult patients in primary care of rural area was relatively high ${ }^{2}$. "Sibela "was one of the primary cares in Surakarta with high prevalence of hypertension. Based on preliminary study, we know that hypertension case increased from 806 cases (in 2017) to 2,567 cases (in 2018).

It was known that mortality risk were significantly increased among hypertension patient especially in untreated or uncontrolled blood pressure ${ }^{3}$. Uncontrolled blood pressure can lead to many complications in some organs including hearth, eyes, brain and peripheral arteries. One of the main causes of uncontrolled blood pressure is noncompliance. It may raise 5 times riskier than compliance patient. About $20-90 \%$ of patients have adverse event experiences due to their antihypertensive drugs ${ }^{4}$.
Study about ADR in hypertension treatment was important to be conducted for optimizing patient safety. Some studies about antihypertensive ADR in Indonesia conducted retrospectively 5,6. Hence, it can not explored patients symptoms deeply. The most popular ADR causality assessment tools in Indonesia was Naranjo. Naranjo tool consist of 10 items question In this study, we used a new active surveillance pharmacovigilance method, published in 2011. It was modified from Naranjo tool to assesses the ADR and routed to more specific question resulting in four causality categories: 'unlikely, 'possible,' 'probable,' and 'definite 7 . The objective of this study was to monitor the ADR caused by antihypertensive drugs prescribed in "Sibela" primary care, Surakarta.

\section{METHODS \\ Settings}

Cross-sectional study was conducted at Sibela Public Health Center, Surakarta, in March 2019. Studied subject were obtained by total sampling. Patients have been treated in antihypertension drugs for at least 1 month (investigators confirmed treatment duration 
within interview), willing to be involved as respondents (informed consent), being able to communicate and read well were included. Meanwhile, respondents who did not answer the questions completely were excluded. This study was approved by ethics research committee in Faculty of Medicine Unviersitas Muhammadiyah Surakarta with ethical clearance no. 2119/B.1/KEPK-FKUMS/V/2019.

\section{Materials}

Patients medical record were extracted to got information about patients' characteristic such as age, sex, occupational states, concomitant disease, and drugs dosing. Data limitations in medical records are complemented by direct interviews during the assessment of ADR. Investigators interviewed patients directly guided by checklist about adverse event of each drugs. Then, ADR were confirmed using Liverpool Algorithm ${ }^{7}$. Unlikely Naranjo tool that used scoring, it used flowchart that easy to follow and quick to complete. We used original version and translated by using back translation in UPT Bahasa Universitas Sebelas Maret.

\section{Data Analysis}

Patients characteristic were analyzed descriptively by explaining the characteristics of each variable. The ADR of each drugs in every prescription calculated to total events of ADR drugs. The total cases of all drugs were calculated from total cases of drug used by patients (one prescription was one case). The result of ADR analysis in each drug interpreted based on Liverpool algorithm, consisting of 4 scales: 'unlikely,' 'possible,' 'probable,' and 'definite.'

\section{RESULTS AND DISCUSSION}

During March 2018, a total of 70 hypertension patient in "Sibela" primary care were enrolled. We observed patients who have been treated for at least 1 month. Since, commonly ADR occurred 2 to 4 weeks after starting new medication or after increasing the dose 8 . We classified period of therapy in less than 6 month, 6-12 month and more than 1 years. Limitation of this study was not associated treatment duration and ADR.

In this study, the prevalence of hypertension increased by age prior to patients more than 46 years old. The characteristic of studied subject was showed in table I. Peoples with age more than 46 years old are more likely to suffer hypertension. It was related to complex and varied factors. Contributing factors of increasing BP related to ageing include decreased baroreceptor sensitivity, increased responsiveness to sympathetic nervous system stimuli, altered renal and sodium metabolism and an altered renin-aldosterone relationship. Increasing blood pressure is associated with rising cardiovascular risk. The significant predictor is increased pulse pressure due to decreased diastolic and increased systolic blood pressure? ${ }^{9}$.

Studied subject were dominated with female (56 patients) than male patients (14 patients). This is triggered by the decrease of estrogen hormone during menopause (40 55 years old). Cardiovascular disease is increases in post menopause women. It was associated to sex hormone, estrogen (E2), that has cardioprotective effect. Estrogen enhanced mitochondrial structure and function, diminishes ROS production, and reduces oxidative stress ${ }^{10}$.

Based on the occupational status, it can be seen that patients who are not working/jobless are more vulnerable to hypertension. The patients whose jobs are related to routine physical activities have less risk of hypertension since the routine physical activities lower the saturated fat, improves the sodium-elimination that occurs due to the change of kidney function, reduce plasma renin and catecholamine activities which may prevent high blood pressure. The reduction in blood pressure with physical activity is estimated to attenuation in peripheral vascular resistance, which related to neurohormonal and structural responses with reductions in sympathetic nerve activity and an increase in arterial lumen diameters ${ }^{11}$. 
Table I. Characteristic of studied subject in "Sibela" primary care

\begin{tabular}{|c|c|c|}
\hline Characteristics $(\mathrm{N}=70)$ & Frequency & Percentage \\
\hline \multicolumn{3}{|l|}{ Age } \\
\hline $46-55$ & 10 & $14 \%$ \\
\hline $56-65$ & 30 & $43 \%$ \\
\hline$>65$ & 30 & $43 \%$ \\
\hline \multicolumn{3}{|l|}{ Gender } \\
\hline Female & 56 & $80 \%$ \\
\hline Male & 14 & $20 \%$ \\
\hline \multicolumn{3}{|l|}{ Treatment duration } \\
\hline$<6$ month & 9 & $12.8 \%$ \\
\hline 6-12 month & 19 & $27.2 \%$ \\
\hline$>1$ years & 42 & $60 \%$ \\
\hline \multicolumn{3}{|l|}{ Occupational status } \\
\hline \multicolumn{3}{|l|}{ Employer : } \\
\hline Trader & 5 & $7.1 \%$ \\
\hline Coolie & 1 & $1.4 \%$ \\
\hline Labour & 4 & $5.7 \%$ \\
\hline Businessman & 1 & $1.4 \%$ \\
\hline Parking officer & 1 & $1.4 \%$ \\
\hline Freelance & 1 & $1.4 \%$ \\
\hline Unemployment & 57 & $81.4 \%$ \\
\hline \multicolumn{3}{|l|}{ Comorbide } \\
\hline Diabetes & 8 & $12 \%$ \\
\hline Cholesterol & 4 & $6 \%$ \\
\hline Uric acid & 2 & $3 \%$ \\
\hline Stomach ulcer & 4 & $6 \%$ \\
\hline Arthritis & 1 & $1.4 \%$ \\
\hline Vertigo & 1 & $1.4 \%$ \\
\hline Uric acid and cholesterol & 3 & $4.2 \%$ \\
\hline Uric acid and Diabetes Melitus & 2 & $3 \%$ \\
\hline Uric acid, Cholesterol and Diabetes Mellitus & 1 & $1.4 \%$ \\
\hline Without comorbide & 44 & $62.8 \%$ \\
\hline
\end{tabular}

In its advanced, hypertension often suffered with comorbidities. Diabetes mellitus and hypertension are common diseases that coexist at a greater frequency than alone. This disease is associated with increase peripheral vascular resistance and vascular smooth muscle contractility through excessive response to norepinephrine and angiotensin II. It caused by vascular remodeling and increased body fluid volume associated with insulin resistance-induced hyperinsulinemia and hyperglycemia ${ }^{12}$.
Table II shows that the most-commonly used antihypertension is the single therapy of CCB-class amlodipine. Amlodipine is a third-generation calcium antagonist of dihydropyridine (DHP) which has an action mechanism by blocking the calcium flow into the smooth muscle of blood vessels and myocardial cells so it can reduce peripheral vascular resistance ${ }^{13}$.

Amlodipin is a long-action and lipophilic drug that can obstruct the oxidative damage in lipid bilayer, in which it prevents 
Table II. Distribution of Antihypertension usage in Sibela primary care

\begin{tabular}{|c|c|c|c|}
\hline Type of Drug & Drugs & Drugs dose & Amout (percentage) \\
\hline \multicolumn{4}{|l|}{ Monotherapy } \\
\hline СCB & Amlodipine $5 \mathrm{mg}$ & 1 tab / day & $56(80 \%)$ \\
\hline ACEi & Captopril $12.5 \mathrm{mg}$ & $1 \mathrm{tab} / 12$ hours & $7(10 \%)$ \\
\hline \multicolumn{4}{|c|}{ Combination therapy } \\
\hline CCB + ACEI & $\begin{array}{l}\text { Amlodipin } 5 \mathrm{mg}+ \\
\text { Captopril } 12.5 \mathrm{mg}\end{array}$ & Each 1 tablet/day & $2(2.8 \%)$ \\
\hline CCB + Diuretik & $\begin{array}{c}\text { Amlodipin } 5 \mathrm{mg}+ \\
\text { Hidroklorotiazid } 25 \mathrm{mg}\end{array}$ & Each 1 tablet/day & $3(4.3 \%)$ \\
\hline ACEi + B-Bloker & $\begin{array}{c}\text { Captopril } 1.25 \mathrm{mg}+ \\
\text { bisoprolol } 5 \mathrm{mg}\end{array}$ & Each 1 tablet/day & $1(1.4 \%)$ \\
\hline $\begin{array}{l}\mathrm{CCB}+\mathrm{ACEi}+ \\
\text { Diuretik }\end{array}$ & $\begin{array}{l}\text { Amlodipin } 5 \mathrm{mg}+ \\
\text { Captopril } 12.5 \mathrm{mg}+ \\
\text { Furosemid } 40 \mathrm{mg} \\
\end{array}$ & Each 1 tablet/day & $1(1.4 \%)$ \\
\hline
\end{tabular}

CCB : Chalcium Chanel Blocker; ACEi : Angiotensin Converting Enzyme Inhibitoer

free radicals and inhibit atherosclerosis formation. It has a high bioavailability (60-80\%), and a slow elimination rate of 40-60 hours. Amlodipine also significantly reduces myocardial infarction by $26 \%$ and ischemic or stroke by $50 \%$. Including in Calcium Chanel Blocker drugs, it can increase the nitric oxide production in heart failure patients. ${ }^{14}$. Thus, the use of amlodipine is preferred because it has many advantages and is one of the drugs that should be available in the primary health care.

Based on table III, NSAID was the most commonly prescribed which is used to treat arthritis or muscle pain in hypertensive patients. Acetaminophen is a less-effective class of NSAID for dealing with pain if compared to other NSAIDs. However, paracetamol is more safe to use by those with cardiovascular disease than NSAIDs ${ }^{15}$. Some respondents are known to get prescription for aspirin. This is because aspirin is a standard antiplatelet therapy for heart and blood vessel disease. The mechanism of aspirin, as an antiplatelet effect, is acetylation of cyclooxygenase in platelets which obstructs the permanent platelet formation ${ }^{16}$. Antiplatelet dose of Aspirin is 75-325 mg/ day ${ }^{17}$.

The use of other drugs are related to the possibility of drug interactions. Based on the study, there are interactions between the use of antihypertensive drugs with NSAIDs. Interactions between NSAIDs and antihypertensive drug occur in ACEI or ARB drug classes, and diuretics but not in the prescription of other classes of antihypertensive drugs 18,19 . If the use of NSAID in hypertension patients is properly controlled, it can reduce the risk of hypotension complications 20,21 .

The use of NSAIDs causes obstruction of prostaglandin and prostacyclin synthesis. Prostaglandin is a compound that has an inhibitory effect on sodium and water reabsorption in the kidneys ${ }^{22}$. Previous study reported that amlodipine was found to be the most common drug associated with ADR. Table IV provided ADR data due to antihypertension drugs in "Sibela" primary care. 
Table III. Distribution of Other Drug-Usage in hypertension Patients

\begin{tabular}{cccc}
\hline Class of Therapy & Drugs & $\begin{array}{c}\text { Number of Prescription } \\
\text { (N=142) }\end{array}$ & Percentage \\
\hline \multirow{3}{*}{ NSAID } & Diclofenac Sodium & 14 & \\
& Acetaminophen & 22 & $37.3 \%$ \\
Mefenamic acid & 13 & \\
Corticosteroids & Aspirin & 4 & $1.4 \%$ \\
& Dexamethasone & 2 & \\
Vitamin & Vitamin B12 & 16 & $26.1 \%$ \\
& Vitamin B6 & 6 & \\
Supplement & Vitamin B1 & 6 & $11.3 \%$ \\
Antigout & Complex Vitamin B & 9 & $3.6 \%$ \\
& Calcium Lactate & 16 & \\
Antihistamines & Allopurinol & 5 & $5.6 \%$ \\
& Ranitidin & 1 & \\
Antidiabetic & Chlorpheniramine & 7 & $8.4 \%$ \\
Anticholesterol & (CTM) & 8 & $2.8 \%$ \\
Antacids & Glimepiride & 4 & $2.8 \%$ \\
Antiangina & Metformin & 4 & $0.7 \%$ \\
\hline
\end{tabular}

\section{Adverse event of amlodipine: drowsiness}

The drowsiness was occurring in 3 respondents with a possible scale. Respondents reported that drowsiness appeared while taking the drug but none if the drug was stopped. It happened repeatedly, so it was supposed to positive rechallenge. Two of them did not have comorbidities and did not use of other drugs (vitamin B1 and calcium lactate) that caused drowsiness. Another one, sometimes used CTM when had sleeping disorder. Drowsiness was suspected to be caused by the amlodipine's effect on the central nervous system, especially on the autonomic nerve ${ }^{23}$. However, it has never been reported before, so it needs further investigation.

Adverse event of amlodipine: Stomach discomfort (abdominal pain, nausea, vomiting)

The nausea happens to 2 respondents with a scale of probable, while the abdominal pain occurs in a respondent with a scale of probable. Respondents were suspected positive rechallenge because abdominal pain followed after taking medications. In one respondent, Amlodipine were used concomitantly with Acetaminophen which also has ADR of nausea. However, respondent previously had never nausea after taking Acetaminophen. This adverse effect is triggered by the nitric and antagonist calcium can lower the sfingter pressure in the esophagus so that it causes gastric acid and GERD ${ }^{24}$. Nausea, vomiting and frequent urination are also often reported after using amlodipine. Amlodipine medication is included in DHP group which has the potential to cause worse gastric disorder than the NDHP group ${ }^{25,26}$.

\section{Adverse event of amlodipine: diuresis}

The diuresis happens to a respondent. Some literatures stated that the use of both single or combined antagonist calcium can increase urinary prevalence by 2.65 times especially in women over 55 years old ${ }^{27}$. In this study, diuresis happens in 77 years old 
Table IV. ADR of antihypertension drugs

\begin{tabular}{|c|c|c|c|c|}
\hline $\begin{array}{c}\text { Medication } \\
\text { Therapy }\end{array}$ & ADR & $\begin{array}{l}\text { Number of } \\
\text { patients }(\%)\end{array}$ & Supporting Data & Scale \\
\hline \multirow[t]{4}{*}{$\begin{array}{l}\text { Amlodipin } \\
(\mathrm{N}=56)\end{array}$} & Drowsiness & $3(5.4 \%)$ & $\begin{array}{l}\text { Positive rechallenge, in one } \\
\text { respondent sometimes used } \\
\text { CTM }\end{array}$ & Possible \\
\hline & Nausea & $2(3.4 \%)$ & $\begin{array}{c}\text { Positive rechallenge, } \\
\text { Concomitant used with } \\
\text { Acetaminophen }\end{array}$ & Probable \\
\hline & $\begin{array}{l}\text { Abdominal pain / } \\
\text { stomach discomfort }\end{array}$ & $1(1.8 \%)$ & Positive rechallenge & Probable \\
\hline & $\begin{array}{l}\text { Increased urinary } \\
\text { frequency }\end{array}$ & $1(1.8 \%)$ & $\begin{array}{l}\text { Diabetes Melitus as } \\
\text { comorbide }\end{array}$ & Probable \\
\hline \multirow[t]{2}{*}{$\begin{array}{l}\text { Captopril } \\
\qquad(\mathrm{N}=7)\end{array}$} & $\begin{array}{l}\text { Dry cough } \\
\text { Dry mouth }\end{array}$ & $1(14.3 \%)$ & $\begin{array}{l}\text { Positive rechallenge } \\
\text { Positive rechallenge }\end{array}$ & Definite \\
\hline & Stomach Pain/Cramp & $1(14.3 \%)$ & $\begin{array}{l}\text { Concomitant used with } \\
\text { mefenamic acid }\end{array}$ & Probable \\
\hline
\end{tabular}

respondent. Diuresis effect related to natriuretic effect of amlodipine, although the occurrence due to the effect is less than $1 \%$. Yet, the effect is reported to increase urine frequency ${ }^{28}$. In this study, diuresis effect may also as consequence of diabetes mellitus in this respondent.

ADR of Captopril: dry cough and mouth

The ADR of dry cough and mouth occur in a respondent with a definite scale. In this study, respondent reported had dry cough after taking captopril and getting better after stop it. According to the literature, dry cough is the most-commonly occurred ADR of using captopril (about 5-20\%). Dry cough can happens immediately within hours after first intake of the dose or delayed in weeks or months later ${ }^{29}$. This ADR correlates to an increase in bradykinin and P-substance that are reversible if the drug is stopped 29,30

The dry cough occurs due to an increase in cough sensitivity, namely formation of bradykinin and prostaglandin. Meanwhile, the dry mouth (rash) is caused by the the sulfhydryl (SH) group on captopril that is not possessed by other ACE-inhibitors. The dry mouth can be reversed when the drug is stopped or antihistmain is given. This ADR is experienced by $10 \%$ of the patients who get captopril therapy. Some effects may also disappear even though the patients continue to consume the drugs ${ }^{31}$.

\section{ADR of Captopril: Abdominal Pain}

The abdominal pain happens on a patient with a probable scale. In this study, beside captopril, respondent also consumed mefenamic acid as symptomatic therapy. Mefenamic acid also reported has ADR of abdominal pain ${ }^{32}$. This ADR may occur due to intestinal angioedema, although it is rarely reported. This angioedema causes swelling of the small intestine that is followed by nausea, vomiting, and / or diarrhea. An Afro-America woman has ever reported the abdominal pain after using drug with the same class, namely lisinopril ${ }^{33}$. Other research mentions that indigestion may happen due to the bradykinin mechanism, which is known to trigger upper respiratory tract angioedema that is connected to the digestive tract ${ }^{34}$.

This study only reports the kinds and the number of ADR without intervention and follow-up to control the ADR found so it needs further investigations. This research still has limitations because the analytical instrument used was the original version and has not been adapted and tested in Indonesia so there is a possibility of bias. 


\section{CONCLUSION}

Adverse drug reactions (ADR) of amlodipine were drowsiness (5.4\%) with a possible scale, nausea $(3.4 \%)$ with a probable scale, diuresis $(1.8 \%)$ with a probable scale, and abdominal pain $(1.8 \%)$ with a probable scale. ADR of captopril were dry cough and dry mouth $(14.3 \%)$ with a definite scale, and abdominal pain $(14.3 \%)$ with a probable scale. Further investigation regarding the drowsiness, ADR of amlodipine, was needed.

\section{CONFLICT OF INTEREST}

The authors have declared "no conflicts of interest"

\section{DAFTAR PUSTAKA}

1. Indonesian Health Ministry. Basic Health Research. Jakarta; 2018.

2. Widjaja FF, Santoso LA, Barus NRV, Pradana GA, Estetika C. Prehypertension and hypertension among young Indonesian adults at a primary health care in a rural area. Med J Indones. 2013;22(1):39-45.

3. Zhou D, Xi B, Zhao M, Wang L, Veeranki SP. Uncontrolled hypertension increases risk of all-cause and cardiovascular disease mortality in US adults: The NHANES III Linked Mortality Study. Sci Rep. 2018;8(1).

4. Tedla YG, Bautista LE. Drug ADR Symptoms and Adherence to Antihypertensive Medication. Am J Hypertens. 2016;29(6):772-779.

5. Paranoan R, Manggau MA, Kasim H, Djide MN, Lallo S, Djabir YY. Analisis Efektivitas Dan Efek Samping Penggunaan Antihipertensi Pada Pasien Gagal Ginjal Kronik Rawat Inap di RSUP Dr. Wahidin Sudirohusodo. Maj Farm dan Farmakol. 2019;23(1):13-15.

6. Kristanti P. Efektifitas Dan Efek Samping Penggunaan Obat Antihipertensi Pada Pasien Hipertensi Di Puskesmas Kalirungkut Surabaya. Calyptra J Ilm Mhs Univ Surabaya. 2015;4(2). https://journal.ubaya.ac.id/index.php/ji mus/article/view/2077/1635. Accessed September 23, 2020.

7. Gallagher RM, Kirkham JJ, Mason JR, et al. Development and inter-rater reliability of the Liverpool adverse drug reaction causality assessment tool. PLoS One. 2011;6(12).

8. Bina D, Komunitas F, Klinik DAN, et al. Pharmaceutical care. 2006.

9. Pinto E. Blood pressure and ageing. 2007:109-114.

https://www.ncbi.nlm.nih.gov/pmc/arti cles/PMC2805932/. Accessed November 11, 2019.

10. Iorga A, Cunningham CM, Moazeni S, Ruffenach G, Umar S, Eghbali M. The protective role of estrogen and estrogen receptors in cardiovascular disease and the controversial use of estrogen therapy. Biol Sex Differ. 2017;8(1):33.

11. Hegde SM, Solomon SD. Influence of Physical Activity on Hypertension and Cardiac Structure and Function. Curr Hypertens Rep. 2015;17(10).

12. Ohishi M. Hypertension with diabetes mellitus: Physiology and pathology review-article. Hypertens Res. 2018;41(6):389-393.

13. Taylor SH. Usefulness of amlodipine for angina pectoris. Am J Cardiol. 1994;73(3).

14. Fares H, DiNicolantonio JJ, O'Keefe JH, Lavie CJ. Amlodipine in hypertension: A first-line agent with efficacy for improving blood pressure and patient outcomes. Open Hear. 2016;3(2):1-7.

15. Turtle EJ, Dear JW, Webb DJ. A systematic review of the effect of paracetamol on blood pressure in hypertensive and non-hypertensive subjects. $\mathrm{Br} J \mathrm{Clin}$ Pharmacol. 2013;75(6):1396-1405.

16. Yunita EP, Zulkarnain BS, Aminuddin M. Aspirin Resistance in Coronary Artery Disease with Hypertensive Patients. Indones $J$ Clin Pharm. 2015;4(1):28-38.

17. Kour D, Tandon VR, B. K, Mahajan A, Parihar A, Smotra S. Aspirin Resistance. JK Sci. 2006;8(2):116-117. 
18. Fournier JP, Sommet A, Bourrel R, et al. Non-steroidal anti-inflammatory drugs (NSAIDs) and hypertension treatment intensification: A population-based cohort study. Eur J Clin Pharmacol. 2012;68(11):1533-1540.

19. Grossman E, Messerli FH. Druginduced hypertension: An unappreciated cause of secondary hypertension. Am J Med. 2012;125(1):1422.

20. Rosenberg A, Agiro A, Gottlieb M, et al. Early trends among seven recommendations from the choosing wisely campaign. JAMA Intern Med. 2015;175(12):1913-1920.

21. Bouck Z, Mecredy GC, Ivers NM, et al. Frequency and Associations of Prescription Nonsteroidal Antiinflammatory Drug Use among Patients with a Musculoskeletal Disorder and Hypertension, Heart Failure, or Chronic Kidney Disease. JAMA Intern Med. 2018;178(11):1516-1525.

22. Landefeld K, Gonzales H, Sander GE. Journal of Clinical Case Reports Hypertensive Crisis: The Causative Effects of Nonsteroidal AntiInflammatory Drugs. J Clin Case Reports. 2016;6(7):10-12.

23. Milovanović B, Trifunović D, Milićević N, Vasić K, Krotin M. The significance of amlodipine on autonomic nervous system adjustment (ANSA Method): A new approach in the treatment of hypertension. Srp Arh Celok Lek. 2009;137(7-8):371-378.

24. Hughes J, Lockhart J, Joyce A. Do calcium antagonists contribute to gastro-oesophageal reflux disease and concomitant noncardiac chest pain? $\mathrm{Br} J$ Clin Pharmacol. 2007;64(1):83-89.

25. Fujita T, Ando K, Nishimura $\mathrm{H}$, et al. Antiproteinuric effect of the calcium channel blocker cilnidipine added to renin-angiotensin inhibition in hypertensive patients with chronic renal disease. Kidney Int.
2007;72(12):1543-1549.

26. Sanghavi, Someshwari, Rajanandh, Seenivasan. Amlodipine Induced Severe Pedal Edema: A Case Report from a Tertiary Care Hospital. J Pharmacovigil. 2017;5(5).

27. Hall SA, Chiu GR, Kaufman DW, Wittert GA, Link CL, McKinlay JB. Commonly used antihypertensives and lower urinary tract symptoms: Results from the Boston Area Community Health (BACH) Survey. BJU Int. 2012;109(11):1676-1684.

28. Galappatthy P, Waniganayake YC, Sabeer MIM, Wijethunga TJ, Galappatthy GKS, Ekanayaka RAI. Leg edema with (S)-amlodipine vs conventional amlodipine given in triple therapy for hypertension: A randomized double blind controlled clinical trial. BMC Cardiovasc Disord. 2016;16(1):1-10.

29. Dicpinigaitis P V. Angiotensinconverting enzyme inhibitor-induced cough: ACCP evidence-based clinical practice guidelines. Chest. 2006;129(1 SUPPL.):169S-173S.

30. Tom B, Dendorfer A, De Vries R, Saxena PR, Danser AHJ. Bradykinin potentiation by ACE inhibitors: A matter of metabolism. Br J Pharmacol. 2002;137(2):276-284.

31. Kumar R, Sharma R, Bairwa K, Roy KR, Kumar A, Baruwa A. Modern Development in ACE inhibitors. Der Pharm Lett. 2010;2(43):388-419.

32. Lacy CF, Armstrong LL, Glodman MP, Lance LL. Drug Information Handbook. 17th Edition. Hudson: Lexi-Comp; 2009.

33. Palmquist S, Mathews B. Isolated intestinal type angioedema due to ACEinhibitor therapy. Clin Case Reports. 2017;5(5):707-710.

34. Celbek G, Aydın Y, Ermiş F, Güngör A, Kutlucan A, Önder E. Rare Acute Pancreatitis Cases Due to Different Antihypertensive Drugs: Four Cases. Acta Medica Anatolia. 2014;3(X-X). 